Amra T. Hodžić Jejna

Kulturni centar Novi Pazar

Multimedijalni centar

Novi Pazar

amrajejna@gmail.com
UDK $371.3:: 811.111$

Originalan naučni rad

10.19090/mv.2016.7.311-328

\title{
STAVOVI NASTAVNIKA ENGLESKOG JEZIKA O UTICAJU VERBALNO-VIZUELNOG MATERIJALA NA USVAJANJE VOKABULARA
}

\begin{abstract}
APSTRAKT
Sredstva vizuelnih komunikacija su način da se informacija na brz i efektan način prenese primaocu. S obzirom da je vokabular veoma važan u procesu učenja engleskog kao stranog jezika, veoma je bitno da se iznađu načini za njegovo što uspešnije usvajanje. Kombinacija slike i reči je od velike pomoći u učenju jezika. Samim tim, postoji veza između učenja vokabulara i verbalno-vizuelnog materijala sa sredstava vizuelnih komunikacija. Putem analize upitnika sastavljenog od pitanja zatvorenog tipa, kao i Likertovih skala stavova, dobijeni su podaci o tome koliko je po mišljenju nastavnika uticaj verbalno-vizuelnog materijala bitan za usvajanje vokabulara engleskog kao stranog jezika. Istraživanje je sprovedeno u osnovnim i srednjim školama u Novom Pazaru, kao i na Univerzitetu u Novom Pazaru.
\end{abstract}

Ključne reči: vokabular, usvajanje engleskog kao stranog jezika, verbalno-vizualni materijal, vizuelne komunikacije, nastavnici, stavovi.

\section{ENGLISH TEACHERS' ATTITUDES TOWARDS THE INFLUENCE OF VISUAL-VERBAL MATERIAL ON VOCABULARY ACQUISITION}

\begin{abstract}
Visual communication is the way to pass the information to the consumer in an effective manner. Considering the fact that vocabulary is very important in the process of EFL learning, it is necessary to find out the ways for its successful acquisition. Word and image combination is of great help in the process of language learning. Therefore, the relation
\end{abstract}


between vocabulary learning and visual-verbal material is present as well. Data about the teachers' attitudes towards the importance of visualverbal material for EFL vocabulary acquisition are analyzed from the questionnaire that consists of closed-ended questions and two Likert scales. The research was conducted in primary and secondary schools in Novi Pazar, and at University of Novi Pazar.

Key words: vocabulary, EFL acquisition, visual-verbal material, visual communication, teachers, attitudes.

\section{UVOD}

Kombinacija slike i reči se koristi u mnogim oblastima poput medija, reklame, vizuelnih i grafičkih studija, ali i u oblasti lingvistike i usvajanja jezika. Jezik se ne može razvijati kao izolovan vid komunikacije i njegova veza sa vizuelnim predstavama je veoma izražena (Britsch, 2010: 171) jer se u mozgu skladište i procesuiraju kako verbalne, tako i vizuelne slike pojmova koje usvajamo i međusobno se stvaraju veze među njima. Kako je učenje vokabulara važan cilj u usvajanju engleskog jezika (Sadoski, 2005: 221) i dobija sve značajnije mesto u nastavi, potrebno je pronaći što efikasnije načine za njegovo uspešno učenje. Verbalno-vizuelni materijal, kako na sredstvima vizuelnih komunikacija, tako i u samoj učionici, može biti veoma dobar način za prezentovanje vokabulara.

Ovaj rad se bavi ispitivanjem stavova i mišljenja nastavnika engleskog jezika o stepenu značaja i važnosti verbalno-vizuelnog materijala u usvajanju vokabulara engleskog kao stranog jezika, a istraživanje je sprovedeno u obrazovnim institucijama u Novom Pazaru. Cilj ovog rada jeste upravo ispitivanje odnosa nastavnika prema ovom vidu nastavnog materijala sa hipotezom da nastavnici engleskog jezika u obrazovnim institucijama u Novom Pazaru imaju pozitivno mišljenje o dejstvu verbalno-vizuelnog materijala sa sredstava vizuelnih komunikacija na usvajanje vokabulara.

\section{VERBALNO-VIZUELNI MATERIJAL U NASTAVI VOKABULARA ENGLESKOG JEZIKA}

U lingvističkim i metodičkim istraživanjima često se postavlja pitanje koliko određeni faktor ima uticaja na učenje i usvajanje jezika (Hodžić Jejna, 2013: 163). Štampani materijal, fotografija i elektronski mediji sadrže ogroman 
broj informacija koje se prezentuju putem kombinacije teksta i slike (Sless, 1981: 15), tako da na taj način svesno ili nesvesno usvajamo i jezik. Kako je vokabular vremenom postao važan segment učenja jezika, istraživanja u ovom polju su mnogobrojna, posebno kada je u pitanju njegovo usvajanje. Istraživanja vezana za fenomen uticaja verbalno-vizuelnog materijala na usvajanje vokabulara engleskog kao stranog jezika nisu tako česta kod nas i u regionu. Đokić i Aleksić (2011) pišu o uticaju interneta na usvajanje vokabulara kod dece, a Tasić i Stamenković (2015) pišu o odnosu verbalne i vizuelne komponente u stripu. Pavičić-Takač (2008) pominje u svom radu prezentaciju novih reči putem verbalno-vizuelnog materijala kao uspešan vid nastave vokabulara.

Brič (Britsch, 2010: 171) navodi da proces razvoja jezika mora biti multimodalni, umesto samo jezički. Plas, Čan, Mejer i Lojtner (Plass, Chun, Mayer i Leutner, 1998) u svom radu pominju brojne prednosti verbalnovizuelnog materijala u usvajanju novih reči i prednosti takvog učenja nad onim za koje se koristi samo jedna ili nijedna anotacija. Šmit (Schmitt, 2008) pominje učenje vokabulara sa sredstava vizuelnih komunikacija kao metakognitivnu strategiju, a Hulstin (Hulstijn, 1997) piše o mnemoničkim tehnikama poput pravljenja vizuelnih predstava reči. Sekmenova (Sökmen, 2009) navodi da kada učenici vizualizuju verbalni materijal koji treba naučiti, mogućnost da se kasnije sete toga je mnogo veća nego kada se prave samo verbalne veze, a Šmit i Šmit (Schmitt i Schmitt, 1995) pominju vizualizaciju veze između već poznate i nove reči. Oksfordova (Oxford, 1990) pominje da je dobar način da se zapamti ono što se čuje ili vidi upravo kreiranje mentalnih slika pojmova. Čan i Plas (Chun and Plass 1993, 1996) su kroz svoje studije dokazali mnogo veću efektivnost kod učenja vokabulara putem anotacija koje sadrže verbalno-vizuelni materijal.

Harmer (Harmer, 2001) piše da su nastavnici oduvek koristili kombinaciju vizuelnih i verbalnih materijala u nastavi. Debes (Debes, 1974 u Spilman et al. 1983: 298) ističe da problem u učenju nastaje onda kada deca uđu u verbalni svet gde se zanemaruju vizuelne veštine koje su ona stekla gledajući televiziju kod kuće. Upravo zbog dečje sposobnosti da komuniciraju na najrazličitije načine koristeći verbalni i vizuelni jezik, nastavnici su danas u ulozi moderatora gde u toku interaktivne nastave učenicima trebaju da pomognu u organizaciji sirovog znanja vizuelnog jezika koje su usvojili tokom života i povežu ga na pravilan način sa verbalnim jezikom (Spilman et al., 1983: 298). 


\section{METODOLOGIJA}

Za ovo istraživanje odabran je uzorak od 52 nastavnika i asistenata na Odseku za anglistiku Univerziteta u Novom Pazaru, kao i nastavnika osnovnih i srednjih škola u Novom Pazaru. Svi nastavnici (N=52) su popunili upitnik koji se ticao njihovih stavova o značaju i uticaju verbalno-vizuelnog materijala na usvajanje vokabulara engleskog kao stranog jezika. Nekim nastavnicima je autorka poslala upitnik putem imejla, tako da su dva upitnika popunjena na taj način. Upitnici su popunjavani i prikupljani u toku aprila i maja 2014. godine.

Upitnik je sastavljen od četiri pitanja, od kojih su dva bila u vidu skale procene, a imao je za cilj da utvrdi:

- opšte podatke o nastavniku (pol, stručna sprema, godine staža, obrazovna institucija u kojoj radi, razredi kojima predaje);

- mišljenje i stavove nastavnika o značaju i stepenu uticaja verbalnovizuelnog materijala na usvajanje vokabulara engleskog jezika;

- mišljenje i stavove nastavnika o značaju verbalno-vizuelnog materijala na usvajanje vokabulara engleskog jezika.

\subsection{Uzorak istraživanja}

Upitnik je sproveden na uzorku $(\mathrm{N}=52)$ sastavljenom od devet nastavnika (profesori i asistenti) engleskog jezika Departmana za filologiju Univerziteta $\mathrm{u}$ Novom Pazaru, 25 nastavnika engleskog jezika u osnovnim školama (OŠ "Stefan Nemanja", OŠ "Bratstvo", OŠ "Jovan Jovanović-Zmaj", OŠ "Aleksandar Stojanović-Leso" i OŠ "Vuk Karadžić") i 18 nastavnika u srednjim školama (Tehnička škola, Škola za dizajn tekstila i kože, Gimnazija, Medicinska škola i Ekonomsko-trgovinska škola) u Novom Pazaru. Anketiranje je sprovedeno u aprilu i maju 2014. godine. Cilj ovog upitnika bio je da se saznaju stavovi i mišljenja nastavnika engleskog jezika vezano za nastavu vokabulara, sa posebnim osvrtom na stavove i mišljenja vezana za upotrebu verbalno-vizuelnog materijala u nastavi engleskog kao stranog jezika, kao i stavove i mišljenja za stepen uticaja verbalno-vizuelnog materijala na učenje engleskog jezika. U radu se polazi od hipoteze da nastavnici engleskog jezika u obrazovnim institucijama u Novom Pazaru imaju pozitivno mišljenje o dejstvu verbalno-vizuelnog materijala sa sredstava vizuelnih komunikacija na usvajanje vokabulara. 


\subsection{Opšti podaci o ispitanicima}

U delu upitnika koji se odnosio na opšte informacije o ispitanicima, bilo je četiri pitanja koja su se odnosila na pol nastavnika, obrazovne institucije u kojima rade, stručnu spremu i godine staža. Navedeni podaci o nastavnicima prikazani su u tabelama koje slede.

\begin{tabular}{|l|l|l|}
\hline Pol nastavnika & frekvencija & $\%$ \\
\hline Ženski & 42 & 80,77 \\
\hline Muški & 10 & 19,23 \\
\hline Ukupno & 52 & 100 \\
\hline
\end{tabular}

Tabela 1. Pol nastavnika

Što se polne strukture nastavnika tiče, iz Tabele 1. može se zaključiti da je procentualno manje nastavnika engleskog jezika muškog pola $(19,23 \%)$ popunilo upitnike, u odnosu na nastavnike engleskog jezika ženskog pola (80,77\%). To je realno stanje što se tiče broja muškaraca koji rade u ovoj struci u Novom Pazaru i autorka je vodila računa da je uzorak sličan populaciji i u ovom smislu.

\begin{tabular}{|l|l|l|}
\hline Institucija u kojoj nastavnik radi & frekvencija & $\%$ \\
\hline Osnovna škola & 25 & 48,10 \\
\hline Srednja škola & 18 & 34,61 \\
\hline Fakultet & 9 & 17,29 \\
\hline ukupno & 52 & 100 \\
\hline
\end{tabular}

Tabela 2. Institucije u kojima su zaposleni nastavnici

Iz Tabele 2. može se zaključiti da je najveći procenat ispitanih nastavnika engleskog jezika zaposlen u osnovnim školama (48,10\%), onda u srednjim školama $(34,61 \%)$ i na kraju na fakultetu (17,29\%). Taj procent je nameran jer je broj nastavnika koji rade u osnovnim školama najveći srazmerno broju škola, nešto manji broj radi u srednjim školama, a značajno manji broj nastavnika (profesora i asistenata) radi na fakultetu. Autorka je vodila računa da uzorak nastavnika bude procentualno zastupljen u uzorku slično kao što je u populaciji nastavnika engleskog jezika u Novom Pazaru. 


\begin{tabular}{|l|l|l|}
\hline Dužina radnog staža nastavnika & frekvencija & $\%$ \\
\hline 0 -10 godina & 20 & 38,46 \\
\hline $11-20$ godina & 27 & 51,92 \\
\hline 21 i više godina & 5 & 9,62 \\
\hline ukupno & 52 & 100 \\
\hline
\end{tabular}

Tabela 3. Dužina radnog staža nastavnika

Analizom upitnika može se videti (Tabela 3) da je najveći broj nastavnika koji rade u nastavi engleskog jezika od 11 do 20 godina $(51,92 \%)$, onda nešto manji broj koji rade od 0 do 10 godina $(38,46 \%)$ i najmanje je nastavnika $(9,62 \%)$ koji u školi rade više od 21 godinu.

\begin{tabular}{|l|l|l|}
\hline Stepen obrazovanja nastavnika & Frekvencija & $\%$ \\
\hline Viša škola & 4 & 7,69 \\
\hline Osnovne studije & 25 & 48,07 \\
\hline Postdiplomske studije & 23 & 44,24 \\
\hline Ukupno & 52 & 100 \\
\hline
\end{tabular}

Tabela 4. Stepen obrazovanja nastavnika

Stepen obrazovanja nastavnika je još jedna važna stavka kod anketiranja, a da bi se autorka uverila da je uzorak valjan, potrudila se da srazmera stepena obrazovanja zastupljena u uzorku bude slična srazmeri zastupljenoj u populaciji nastavnika engleskog jezika u Novom Pazaru. Tako, veoma je malo zastupljeno nastavnika sa završenom višom školom $(7,69 \%)$ i to su uglavnom stariji nastavnici koji su već pred penzijom. Najviše je onih sa završenim osnovnim studijama (48,07\%), a s obzirom na to da je poslednjih nekoliko godina uslov da nastavnici imaju završene master studije da bi mogli da rade u nastavi, veliki je broj i nastavnika sa završenim postdiplomskim studijama (44,24\%).

\section{REZULTATI ISTRAŽIVANJA}

Deskriptivnom statističkom analizom odgovora zatvorenog tipa i dve skale stavova biće utvrđeni: (1) mišljenje i stav nastavnika o tome na koji element jezika najviše utiče upotreba verbalno-vizuelnog materijala; (2) mišljenje i 
stav nastavnika o stepenu uticaja verbalno-vizuelnog materijala na usvajanje engleskog kao stranog jezika; (3) mišljenje i stavovi nastavnika o vrstama verbalno-vizuelnog materijala koji se koriste u nastavi i njihovom uticaju na usvajanje vokabulara; (4) mišljenje i stavovi nastavnika o značaju verbalnovizuelnog materijala u nastavi engleskog kao stranog jezika.

\subsection{Pitanja zatvorenog tipa}

Prvo pitanje u Upitniku za nastavnike bilo je Da li upotreba verbalnovizuelnog materijala u nastavi engleskog jezika najviše utiče na usvajanje vokabulara, gramatike, izgovora ili sintaksičkih struktura. Iz rezultata istraživanja predstavljenih u Tabeli 5. može se zaključiti da su skoro svi nastavnici, nezavisno od obrazovne institucije u kojoj rade, bili mišljenja da $\mathrm{VVM}^{1}$ najviše utiču na usvajanje vokabulara engleskog kao stranog jezika $(96,16$ $\%)$.

\begin{tabular}{|l|l|l|}
\hline Jezički elementi na čije usvajanje najviše utiče upotreba VVM & frekvencija & $\%$ \\
\hline Vokabular & 50 & 96,16 \\
\hline Gramatika & 1 & 1.92 \\
\hline Izgovor & 0 & 0 \\
\hline Sintaksičke strukture & 1 & 1,92 \\
\hline Ukupno & 52 & 100 \\
\hline
\end{tabular}

Tabela 5. Uticaj VVM na usvajanje jezičkih elemenata (mišljenja nastavnika)

U Dijagramu 1 se detaljnije može videti (podeljeno po obrazovnim institucijama u kojima nastavnici rade) da je samo jedan nastavnik u osnovnoj školi (1,92\%) bio mišljenja da je uticaj VVM najveći na usvajanje gramatike i jedan nastavnik osnovne škole (1,92\%) je bio mišljenja da je uticaj VVM najveći na usvajanje sintaksičkih struktura. Svi ispitani nastavnici srednjih škola $(100 \%)$ i nastavnici na fakultetu (100\%) su bili mišljenja da je taj uticaj najveći na usvajanje vokabulara. Dakle, nezavisno od obrazovne institucije u kojoj rade, nastavnici su mišljenja da je uticaj VVM na usvajanje vokabulara veliki.

1 skr. verbalno-vizuelni materijal 


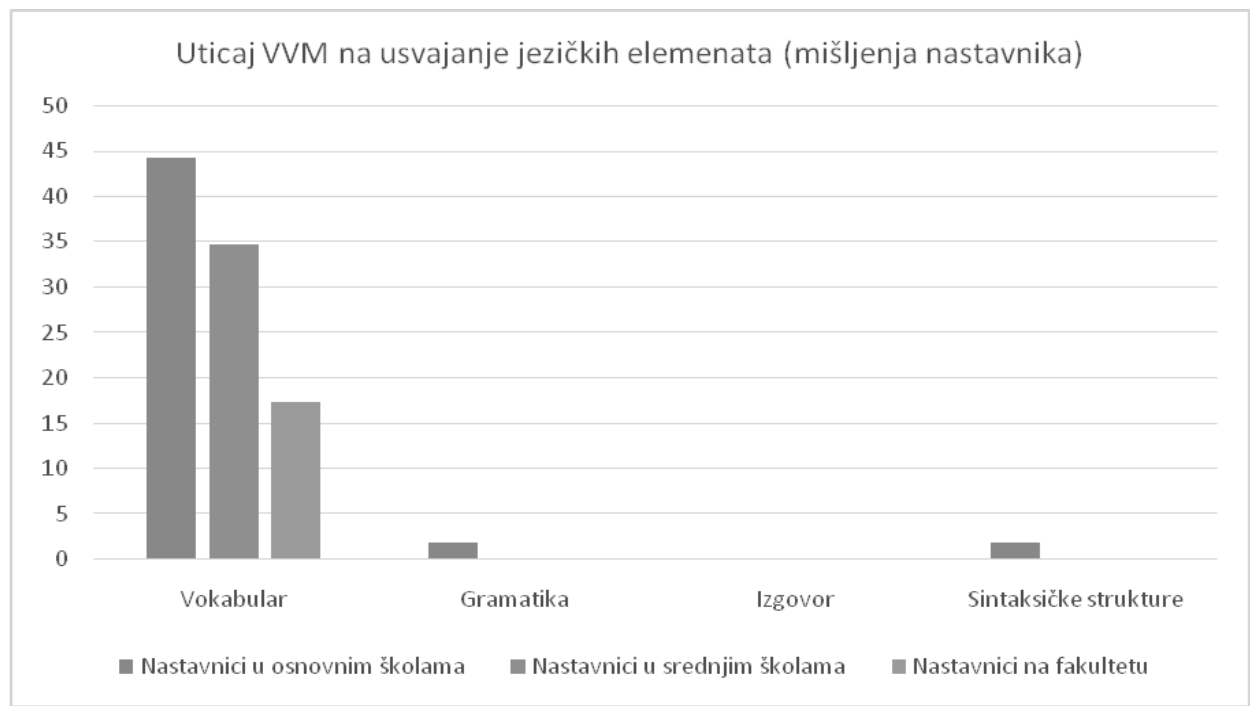

Dijagram 1. Uticaj VVM na usvajanje jezičkih elemenata (mišljenja nastavnika)

Drugo pitanje u Upitniku upućeno nastavnicima je bilo Da li verbalnovizuelni materijal, po Vašem mišljenju, utiče na usvajanje vokabulara vrlo malo, umereno ili mnogo. Iz podataka analiziranih i predstavljenih u Tabeli 6. može se zaključiti da su većina nastavnika engleskog jezika (94,23\%) bili mišljenja da VVM u velikoj meri utiče na usvajanje vokabulara engleskog kao stranog jezika.

\begin{tabular}{|l|c|c|}
\hline Mišljenje o stepenu uticaja VVM na usvajanje vokabulara & frekvencija & $\%$ \\
\hline Vrlo malo & 0 & 0 \\
\hline Umereno & 3 & 5,77 \\
\hline Mnogo & 49 & 94,23 \\
\hline ukupno & 52 & 100 \\
\hline
\end{tabular}

Tabela 6. Stepen uticaja VVM na usvajanje vokabulara (mišljenja nastavnika)

Detaljnija situacija (podeljeno po vrstama obrazovnih institucija u kojima nastavnici rade) je prikazana u Dijagramu 6, gde se može videti da su samo dva nastavnika u srednjim školama $(3,84 \%)$ i jedan nastavnik u osnovnoj školi $(1.92 \%)$ bili mišljenja da je taj uticaj umeren, dok su ostali bili mišljenja da je uticaj velik. Svi nastavnici koji rade na fakultetu (100\%) su bili mišljenja da je uticaj VVM na usvajanje vokabulara velik. 


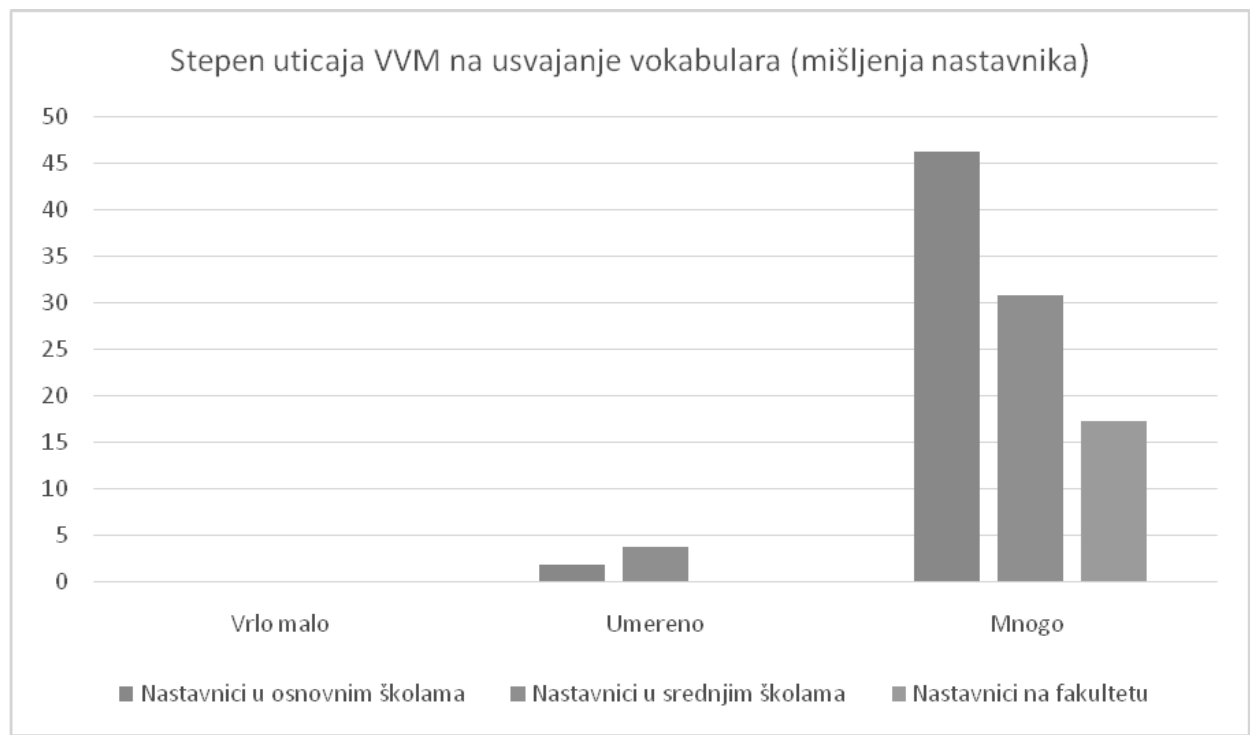

Dijagram 2. Stepen uticaja VVM na usvajanje vokabulara (mišljenja nastavnika)

\subsection{Skala stavova 1}

Treći deo Upitnika za nastavnike sastoji se iz dve skale stavova koje se odnose na stavove nastavnika o značaju verbalno-vizuelnog materijala (sredstava vizuelnih komunikacija) u usvajanju vokabulara engleskog kao stranog jezika.

Prva skala stavova, koja se tiče sredstava vizuelnih komunikacija koja imaju najviše uticaja na usvajanje vokabulara engleskog kao stranog jezika, sastoji se od 9 vrsta verbalno-vizuelnog materijala i trostepene skale raspona od nema uticaja preko delimično do ima uticaja. U ovom slučaju petostepena Likertova skala je zamenjena trostepenom.

\begin{tabular}{|l|c|c|c|}
\hline $\begin{array}{c}\text { VRSTE } \\
\text { VERBALNO-VIZUELNOG } \\
\text { MATERIJALA }\end{array}$ & $\begin{array}{c}\text { NEMA } \\
\text { UTICAJA }\end{array}$ & DELIMIČNO & $\begin{array}{c}\text { IMA } \\
\text { UTICAJA }\end{array}$ \\
\hline $\begin{array}{l}\text { a. Plakati } \\
\text { (fotografija i tekst) }\end{array}$ & 0 & 21,15 & 78,85 \\
\hline $\begin{array}{l}\text { b. Bilbordi } \\
\text { (fotografija i tekst) }\end{array}$ & 0 & 26,92 & 73,08 \\
\hline c. Veb-stranice & 0 & 42,31 & 57,69 \\
\hline
\end{tabular}




\begin{tabular}{|c|c|c|c|}
\hline d. Dijagrami i tabele & 15,38 & 69,24 & 15,38 \\
\hline e. Značenjske mape & 5,77 & 50 & 44,23 \\
\hline $\begin{array}{l}\text { f. Ilustracije (crteži, karikature, } \\
\text { stripovi) }\end{array}$ & 0 & 11,54 & 88,46 \\
\hline $\begin{array}{l}\text { g. Piktogrami (simboli) } \\
\text { i tekst } \\
\end{array}$ & 1,92 & 26,92 & 71,15 \\
\hline h. Slikovni rečnici & 1,92 & 30,77 & 67,31 \\
\hline $\begin{array}{l}\text { i. Novinski naslovi i reklame } \\
\text { (tekst } \\
\text { i fotografija/crtež) }\end{array}$ & 0 & 34,61 & 65,39 \\
\hline
\end{tabular}

Tabela 7. Skala stavova nastavnika engleskog jezika o značaju sredstava $\mathrm{VK}^{2}$ za usvajanje vokabulara

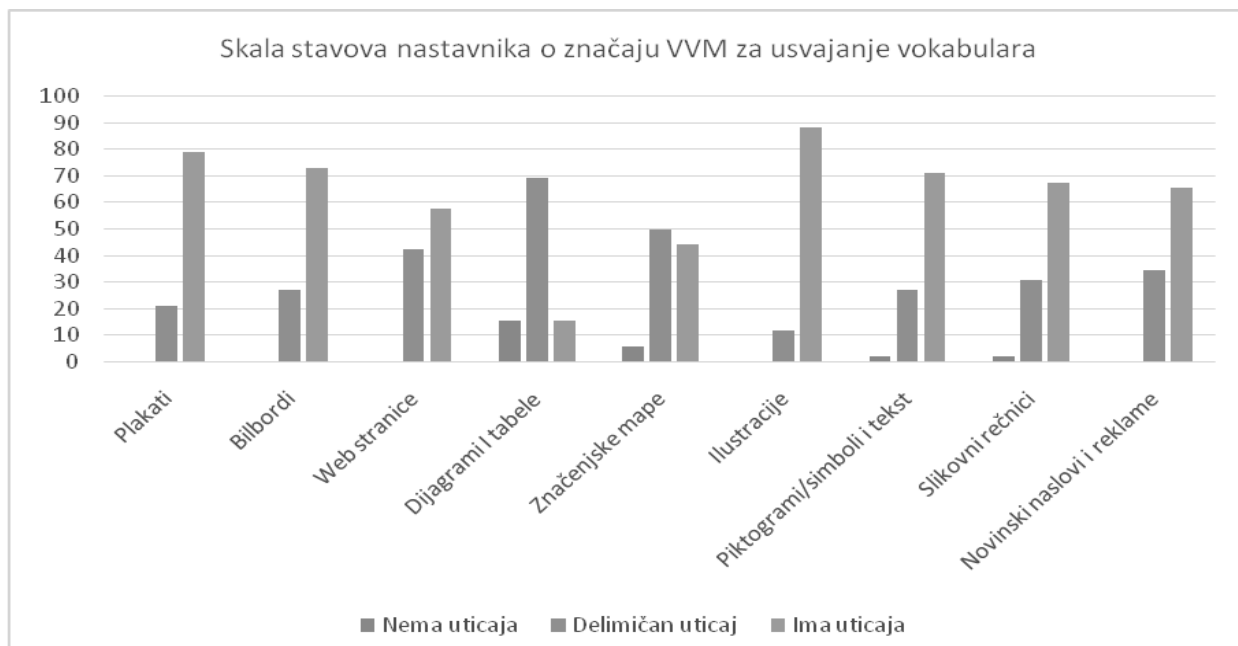

Dijagram 3. Skala stavova nastavnika engleskog jezika o značaju vrsta VVM za usvajanje vokabulara

Iz Tabele 7 i Dijagrama 3 možemo iščitati rezultate dobijene analizom i obradom podataka gde se jasno može videti da nastavnici u obrazovnim institucijama u Novom Pazaru su stava da najviše uticaja (preko 50\%) na usvajanje verbalno-vizuelnog materijala imaju (redom po jačini uticaja):

2 skr. vizuelne komunikacije 
1. ilustracije

2. plakati

3. bilbordi

4. piktogrami/simboli

5. slikovni rečnici

6. novinski članci i reklame

7. veb-stranice.

Kod značaja dijagrama i tabela, kao i značenjskih mapa, za usvajanje vokabulara podeljena su mišljenja $i$ ispitanici smatraju da je uticaj tih sredstava vizuelnih komunikacija delimičan ili da ga nema.

\subsection{Skala stavova 2}

Druga skala stavova, sastoji se od niza od 13 tvrdnji vezanih za usvajanje vokabulara engleskog kao stranog jezika uz pomoć verbalno-vizuelnog inputa i prirodu značaja takve nastave. Ovo je petostepena Likertova skala i odgovori se kreću od sasvim se slažem do uopšte se ne slažem.

\begin{tabular}{|l|c|c|c|c|c|}
\hline \multicolumn{1}{|c|}{ TVRDNJE } & $\mathbf{1}$ & $\mathbf{2}$ & $\mathbf{3}$ & $\mathbf{4}$ & $\mathbf{5}$ \\
\hline $\begin{array}{l}\text { 1. Usvajanje vokabulara engleskog } \\
\text { jezika je efektnije uz upotrebu } \\
\text { verbalno-vizuelnog materijala. }\end{array}$ & 88,46 & 11,54 & $/$ & $/$ & $/$ \\
\hline $\begin{array}{l}\text { 2. Usvajanje vokabulara engleskog } \\
\text { jezika uz upotrebu verbalno- } \\
\text { vizuelnog materijala je interesantnije. }\end{array}$ & 88,46 & 11,54 & $/$ & / & / \\
\hline $\begin{array}{l}\text { 3. Usvajanje vokabulara engleskog } \\
\text { jezika uz upotrebu verbalno- } \\
\text { vizuelnog materijala je lakše za } \\
\text { razumevanje. }\end{array}$ & 84,61 & 15,39 & $/$ & $/$ & $/$ \\
\hline $\begin{array}{l}\text { 4. Usvajanje vokabulara engleskog } \\
\text { jezika uz upotrebu verbalno- } \\
\text { vizuelnog materijala je lakše za } \\
\text { memorisanje. }\end{array}$ & 84,61 & 15,39 & $/$ & / \\
\hline $\begin{array}{l}\text { 5. Nastava vokabulara engleskog jezika } \\
\text { uz upotrebu verbalno-vizuelnog } \\
\text { materijala ima veći uticaj na onoga } \\
\text { ko uči. }\end{array}$ & 69,23 & 28,85 & / & 1,92 & / \\
\hline
\end{tabular}




\begin{tabular}{|c|c|c|c|c|c|}
\hline $\begin{array}{l}\text { 6. Svrha verbalno-vizuelnog materijala } \\
\text { u nastavi vokabulara engleskog } \\
\text { kao stranog jezika je da pokaže } \\
\text { kako izgleda reč ili pojam koji reč } \\
\text { označava. }\end{array}$ & 53,85 & 44,23 & 1,92 & I & I \\
\hline $\begin{array}{l}\text { 7. Svrha verbalno-vizuelnog materijala } \\
\text { u nastavi vokabulara engleskog kao } \\
\text { stranog jezika je da pokaže kako } \\
\text { nešto funkcioniše. }\end{array}$ & 30,76 & 51,92 & 13,49 & 3,84 & I \\
\hline $\begin{array}{l}\text { 8. Svrha verbalno-vizuelnog materijala } \\
\text { u nastavi vokabulara engleskog kao } \\
\text { stranog jezika je da pokaže kako su } \\
\text { stvari povezane jedna sa drugom. }\end{array}$ & 36,54 & 51,92 & 11,54 & I & I \\
\hline $\begin{array}{l}\text { 9. Svrha verbalno-vizuelnog materijala } \\
\text { u nastavi vokabulara engleskog kao } \\
\text { stranog jezika je da istakne važne } \\
\text { stvari. }\end{array}$ & 48,08 & 32,70 & 11,54 & 7,68 & I \\
\hline $\begin{array}{l}\text { 10. Upotreba verbalno-vizuelnog } \\
\text { materijala najviše utiče na usvajanje } \\
\text { pravilnog značenja reči. }\end{array}$ & 30,76 & 57,70 & 11,54 & / & I \\
\hline $\begin{array}{l}\text { 11. Upotreba verbalno-vizuelnog } \\
\text { materijala najviše utiče na usvajanje } \\
\text { pravilnog pisanja reči. }\end{array}$ & 44,23 & 42,32 & 5,77 & 3,84 & 3,84 \\
\hline $\begin{array}{l}\text { 12. Upotreba verbalno-vizuelnog } \\
\text { materijala najviše utiče na usvajanje } \\
\text { pravilnog oblika reči. }\end{array}$ & 51,91 & 28,86 & 15,39 & 3,84 & I \\
\hline $\begin{array}{l}\text { 13. Upotreba verbalno-vizuelnog } \\
\text { materijala najviše utiče na usvajanje } \\
\text { pravilne upotrebe reči u kontekstu. }\end{array}$ & 55,77 & 21,15 & 17,31 & 5,77 & I \\
\hline
\end{tabular}

Tabela 8. Skala stavova nastavnika engleskog jezika o prirodi značaja VVM za usvajanje vokabulara (1 - sasvim se slažem; 2 - uglavnom se slažem; 3 neodlučan sam; 4 - uglavnom se ne slažem; 5 - uopšte se ne slažem). 


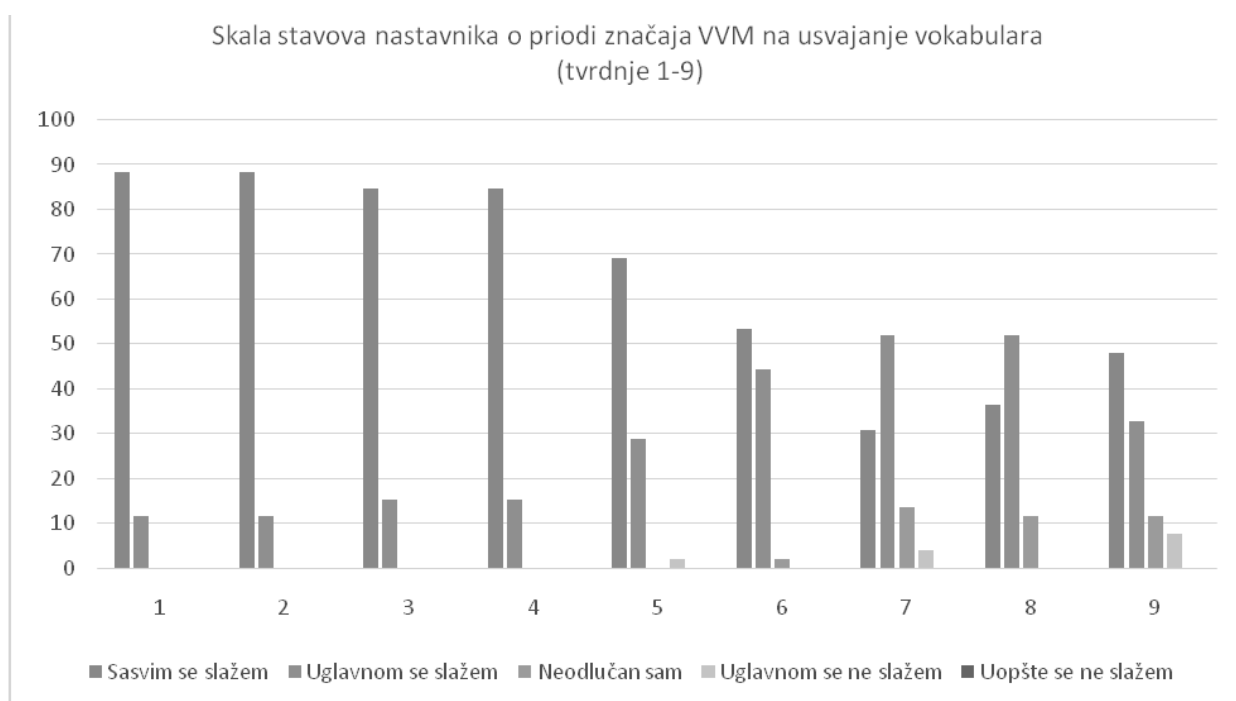

Dijagram 4. Skala stavova nastavnika o prirodi značaja VVM na usvajanje vokabulara (tvrdnje 1-9)

Iz Tabele 8. mogu se iščitati rezultati istraživanja sprovedenog putem skale stavova. Zarad boljeg pregleda rezultata rezultati su predstavljeni i grafički, i to prvih devet tvrdnji u Dijagramu 4, a poslednje četiri tvrdnje u Dijagramu 5.

Prve četiri tvrdnje odnose se na efektivnost, zanimljivost, lakše razumevanje i lakše memorisanje u procesu usvajanja vokabulara engleskog kao stranog jezika ukoliko je prisutan i verbalno-vizuelni input u nastavi i može se zaključiti da su se svi nastavnici sasvim ili uglavnom složila sa njima $(100 \%)$. Nije bilo nijednog nastavnika koji je bio neodlučan ili se nije slagao sa tvrdnjama. Peta tvrdnja se tiče toga da nastava vokabulara engleskog jezika uz upotrebu verbalno-vizuelnog materijala ima veći uticaj na učenike i iz Dijagrama 4. i Tabele 8. može se zaključiti da se većina nastavnika sasvim ili uglavnom složila (98\%). Šesta, sedma, osma i deveta tvrdnja se odnose na svrhu verbalno-vizuelnog materijala u nastavi vokabulara engleskog kao stranog jezika da pokaže kako izgleda reč ili pojam koji reč označava, da pokaže kako nešto funkcioniše, da pokaže kako su stvari povezane jedna s drugom i da istakne važne stvari. Kod šeste tvrdnje skoro svi nastavnici su se sasvim ili uglavnom složili (98\%), a kod sedme, osme i devete se približno $80 \%$ nastavnika složilo sa tvrdnjama, dok je manji procenat bio neodlučan ili se uglavnom nije slagao (manje od 20\%). Međutim, ni kod te tri tvrdnje nije bilo nastavnika koji se uopšte nisu složili. 


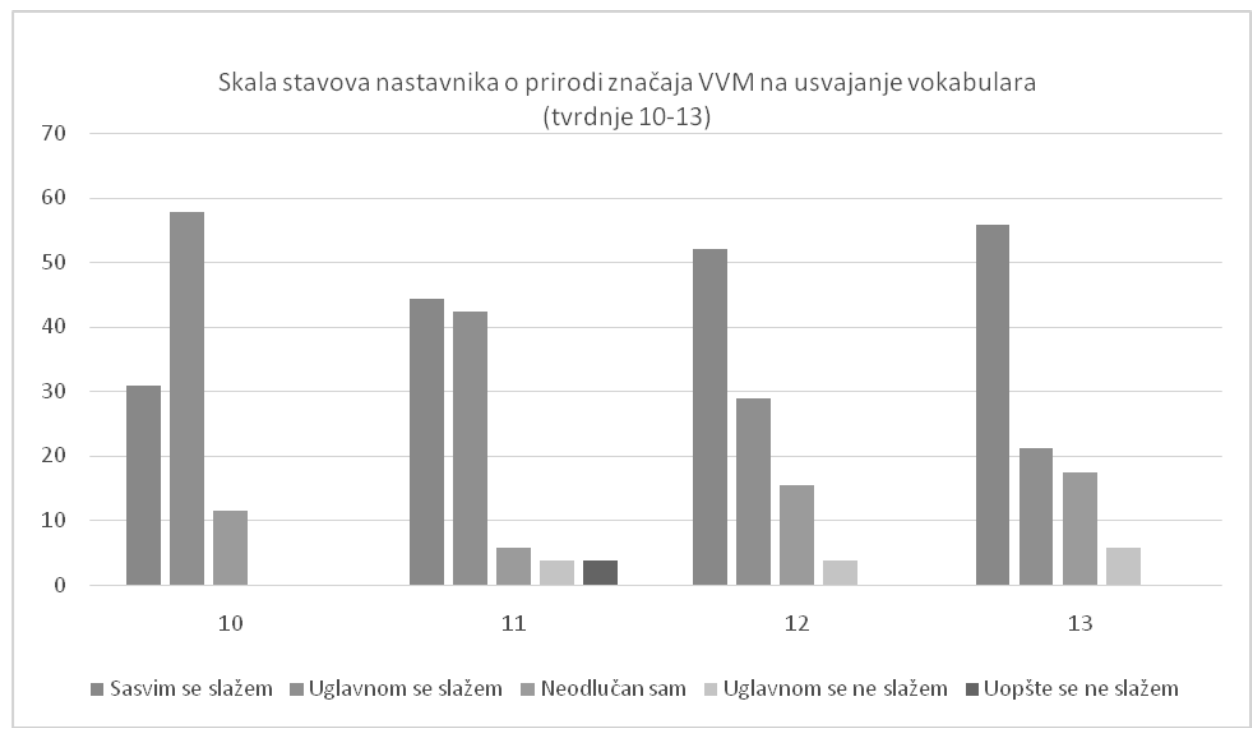

Dijagram 5. Skala stavova nastavnika o prirodi značaja VVM na usvajanje vokabulara (tvrdnje 10-13)

Iz Dijagrama 5. i Tabele 8. mogu se iščitati rezultati desete, jedanaeste, dvanaeste i trinaeste tvrdnje. Ove četiri tvrdnje se odnose na stavove nastavnika engleskog jezika o pozitivnom uticaju verbalno-vizuelnog materijala na usvajanje pravilnog značenja, pravilnog pisanja, pravilnog oblika reči, kao i pravilne upotrebe reči u kontekstu. Uopšteno se može reći da se većina nastavnika složila sa tvrdnjama i da su stava da upotreba verbalno-vizuelnog materijala u nastavi vokabulara može imati pozitivan uticaj na usvajanje reči. Sa desetom tvrdnjom vezanom za pravilno značenje reči 88,46 \% nastavnika se sasvim ili uglavnom složilo. Sa jedanaestom tvrdnjom koja se odnosila na usvajanje pravilnog pisanja se $86,55 \%$ nastavnika složilo, a $13,45 \%$ je bilo neodlučno ili se nisu složili. Dvanaesta tvrdnja se ticala usvajanja pravilnog oblika reči i $80.77 \%$ nastavnika se sasvim ili uglavnom složilo, dok $19,23 \%$ su bili neodlučni ili se uglavnom nisu složili. Nije bilo nastavnika koji se uopšte nisu složili sa tvrdnjom. Slična situacija je i sa trinaestom tvrdnjom koja se odnosila na pravilnu upotrebu reči u kontekstu, gde se 76,92\% nastavnika složilo, dok su 23,08\% bili ili neodlučni ili se delimično nisu slagali. Ni kod ove tvrdnje nije bilo nastavnika koji se uopšte nisu složili.

Iz analize upitnika može se utvrditi da su nastavnici, nezavisno od obrazovne institucije u kojoj rade, mišljenja da verbalno-vizuelni materijal 
ima znatno veći uticaj na usvajanje vokabulara engleskog jezika, nego na usvajanje gramatike, izgovora ili sintaksičkih struktura. Ranija istraživanja su se uglavnom bavila ispitivanjem ovog fenomena kod učenika mlađeg uzrasta, a iz sprovedenog istraživanja vidimo da su nastavnici mišljenja da se ovakav vid nastave može obavljati kako sa učenicima osnovnih i srednjih škola, tako i sa studentima. Kod mlađih učenika slike su dominantne u odnosu na pisanu reč i kod njih je veoma bitno povezivati reči sa njihovim vizuelnim predstavama jer je to način na koji oni najbolje pamte. Upravo iz tog razloga se u tom uzrastu koriste bogato ilustrovani udžbenici. Kod starijih učenika i studenata, mogu se koristiti različiti multimedijalni načini prezentacije vokabulara poput veb stranica, PPT prezentacija i sl, ali i dijagrami i semantičke mape, jer je to način da se apstraktne stvari transformišu u konkretne, grupišu i lakše nauče. Ono što je važno napomenuti jeste da verbalno-vizuelni materijal, ukoliko je dobro osmišljen i prilagođen uzrastu učenika, može biti od veoma velike pomoći nastavniku u podučavanju vokabulara jer učenici neće uvek usvojiti nove reči ukoliko samo čitaju ili slušaju. Korišćenje verbalno-vizuelnog materijala, bilo da je u pitanju ilustracija, plakat ili veb stranica, po mišljenju nastavnika, podstiče aktivnost učenika tokom časa, te samim tim čini nastavu zanimljivijom. Nastavnici su takođe mišljenja da je uticaj dijagrama, tabela i značenjskih mapa slabiji od gorenavedenog, kada je u pitanju usvajanje novih reči, ali to opet ne znači da ih ne treba koristiti u nastavi.

Kako su nastavnici mišljenja da je korišćenje verbalno-vizuelnog materijala veoma interesantan i efektan način prezentacije vokabulara, te da učenici tako lakše i bolje usvajaju nove reči, potrebno je da nastava vokabulara bude kreativnije osmišljena. Iz tog razloga nastavnici se moraju više interesovati za savladavanje osnovnih elemenata vizuelnog jezika da bi na pravilan i odgovarajući način upotpunili svoje časove upotrebom sredstava vizuelnih komunikacija. Samo tako se uspešno može podstaći povezivanje verbalnog i vizuelnog znanja kod mlađih učenika, a korišćenje ove strategije kod starijih učenika i studenata u cilju što bolje retencije vokabulara engleskog kao stranog jezika.

\section{ZAKLJUČAK}

Iz svega navedenog može se zaključiti da su nastavnici mišljenja da verbalno-vizuelni materijal u velikoj meri utiče na usvajanje vokabulara. Što se tiče sredstava vizuelnih komunikacija, oni su stava da najviše uticaja imaju ilustracije, plakati, bilbordi, piktogrami/simboli, slikovni rečnici, novinski članci, 
reklame i veb stranice, dok po njihovom mišljenju dijagrami, tabele i značenjske mape imaju nešto manji uticaj nego gorenavedeno. Nastavnici se slažu da se ovakvom nastavom postiže bolja efektivnost i zanimljivost nastave, kao i lakše razumevanje i memorisanje reči kod učenika i studenata. Nastavnici se potpuno ili uglavnom takođe slažu (98\%) oko toga da ovakav vid nastave ima veliki uticaj na učenike kod usvajanja vokabulara, a što se tiče usvajanja značenja, pisanja i oblika reči nastavnici su takođe bili izrazito pozitivnog mišljenja (u proseku preko $85 \%$ se potpuno ili uglavnom složilo sa tvrdnjama).

Opšti zaključak izveden iz ovog istraživanja je da su nastavnici u obrazovnim institucijama u Novom Pazaru veoma svesni značaja i pozitivnog uticaja verbalno-vizuelnog materijala na usvajanje vokabulara engleskog kao stranog jezika. Nastavnici se slažu da se ovakvom nastavom postiže bolja efektivnost i zanimljivost nastave, kao i lakše razumevanje i memorisanje reči kod učenika osnovnih, srednjih škola i kod studenata, kao i bolje usvajanje značenja, pisanja i oblika reči.

\section{LITERATURA}

Britsch, S. (2010). Photo-Booklets for English Language Learning: Incorporating Visual Communication into Early Childhood Teacher Preparation, Early Childhood Education J, 38, 171-177.

Chun, D. \& Plass, J. (1996). Effects of multimedia annotations on vocabulary acquisition. The Modern Language Journal, 80(2), 183-198.

Debes, J. L. (1974). Mind, languages, and literacy. Paper presented at the Annual Convention of the National Council of Teachers of English, New Orleans.

Harmer, J. (2001). The Practice of English Language Teaching. Longman. (pristupljeno 13.01.2014. u 22:33 http://www.lognostics.co.uk/vlibrary/ meara1996c.pdf)

Hodžić Jejna, A. (2011). Upotreba audiovizuelnih nastavnih sredstava u nastavi engleskog jezika u obrazovnim institucijama na teritoriji Novog Pazara. Zbornik radova Univerzitetska misao, br.10, str. 64-77.

Hodžić Jejna, A. (2013). Uticaj medija na razvoj vokabulara engleskog kao stranog jezika. Zbornik radova Univerzitetska misao 12 (3), str. 163-174.

Hulstijn, J.H. (1997). Mnemonic methods in foreign language vocabulary learning u Coady, J. I T. Huckin. (2003). Second Language Vocabulary Acquisition, Cambridge University Press, Cambridge

Nation, I. S. P. (2001). Learning Vocabulary in Another Language. Cambridge: Cambridge University Press. 
Oxford, R. (1990). Language learning strategies: What every teacher should know. New York: Newbury house.

Pavičić-Takač, V. (2008). Vocabulary learning strategies and foreign language acquisition. Clevedon: Multilingual Matters Ltd.

Plass, J. L., Chun, D. M., Mayer, R. E., \& Leutner, D. (1998). Supporting visual and verbal learning preferences in a second language multimedia learning environment, Journal of Educational Psychology, 90, 25-36. (pristupljeno 15.1.2014. u 00:16 http://www.languageinindia.com/nov2002/vocabulary. html)

Sless, D. (1981). Learning and Visual Communication. London: A Halsted Press Book.

Spilman, C., Clayback Linder, J. \& Goforth, F. (1983). Visual Communication in the Classroom: Concepts and Applications. Contemporary Education, 54 (4): 295-298.

Tasić, M. i Stamenković, D. (2015). Analiza diskursa u vizuelnom jeziku stripa. U Jezik, književnost, diskurs jezička istraživanja, Zbornik radova Filozofski fakultet u Nišu. 203-218.

Sadoski, M. (2005). A Dual Coding View of Vocabulary Learning, Reading \& Writing Quarterly, 21:3, 221-238.

Schmitt N. (2008). Vocabulary in Language Teaching, Cambridge University Press, New York.

Schmitt, N. \& Schmitt, D. (1995). Vocabulary notebooks: theoretical underpinnings and practical suggestions. ESL Journal 49(2): 133-143.

Sökmen, A. (1997). Current trends in teaching second language vocabulary. In N. Schmitt \& M, Michael (Eds.) (1997). Vocabulary: Description, acquisition and pedagogy (pp. 237- 257). Cambridge: Cambridge University Press. 
Amra Hodžić Jejna

Culture Center Novi Pazar

Multimedia Center

Novi Pazar

amrajejna@gmail.com

\section{ENGLISH TEACHERS' ATTITUDES TOWARDS THE INFLUENCE OF VISUAL- VERBAL MATERIAL ON VOCABULARY ACQUISITION}

\section{Summary}

Visual communication is the way to pass the information to the consumer in an effective manner. Concerning the fact that vocabulary is very important in the process of EFL learning, it is necessary to find out the ways for its successful acquisition. Word and image combination is of great help in the process of language learning. Therefore, the relation between vocabulary learning and visual-verbal material is present as well. Data about the teachers' attitudes towards the importance of visual-verbal material for EFL vocabulary acquisition are analyzed from the questionnaire that consists of closed-ended questions and two Likert scales. The research was conducted in primary and secondary schools in Novi Pazar, and at University of Novi Pazar.

Key words: vocabulary, EFL acquisition, visual-verbal material, visual communication, teachers, attitudes.

Primljeno: 2. 5. 2016.

Prihvaćeno: 18. 5. 2016. 